Selcuk Journal of Agriculture and Food Sciences

http://sjafs.selcuk.edu.tr/sjafs/index

Research Article
SJAFS

(2020) 34 (1), 42-48

e-ISSN: 2458-8377

DOI:10.15316/SJAFS.2020.193

\title{
The Change of Wear Element in Engine Lubricating Oil in Diesel Engines Using Biofuel
}

\author{
Ayşe Betül BALCI ${ }^{1, *}$, Hakan Okyay MENGEŞ ${ }^{2}$ \\ ${ }^{1}$ Arrkan Engineering and Consulting Firm, Konya, Turkey \\ ${ }^{2}$ Selçuk University, Faculty of Agriculture, Agricultural Machineries and Tecnologies Engineering, Konya, Turkey
}

\begin{tabular}{l}
\hline ARTICLE INFO \\
\hline Article history: \\
Received date: 18.08 .2019 \\
Accepted date: 14.01 .2020 \\
\hline Edited by: \\
Osman ÖZBEK; Selçuk University, \\
Turkey \\
Reviewed by: \\
Fatih AYDIN; Necmettin Erbakan Uni- \\
versity, Turkey \\
Hüseyin ÖĞ̈̈T; Selçuk University, \\
Turkey \\
\hline Keywords: \\
Biodiesel, \\
Bioethanol, \\
Engine Lubricating Oil, \\
Wear Element \\
\hline
\end{tabular}

\section{Introduction}

In general, the materials used to separate the two solids from each other and to facilitate the movement by minimizing the friction force is called "lubricant" or "oil". The work carried out by the substance between these two soilds is called lubricating (Anonymous, 2011b).

The task of the engine oil is to prevent mechanical wear and reduce power loss by forming a thin film between moving surfaces. In addition, apart from the lubrication of moving parts of the machine; lubricating oil has functions such as reducing friction losses, ensuring the cooling of the surface by absorbing the heat generated by the friction in moving parts like pistons, neutralizing acids formed during combustion and preventing deposits on the surface. Engine oil analysis is performed to check the condition of used engine oil. Various oil analysis techniques determine how far away the engine oil is from its initial state (Müjdeci, 2009).

The oil put into the crankcase starts to get dirty and lose its lubrication ability from the moment it begins to

\footnotetext{
* Corresponding author email:abetulbalci@gmail.com
}

circulate in the system. The loss of lubricating property of the oil depends on the proportion of foreign wastes collected in it. Carbon deposits occur on the combustion chamber surfaces during the running of the engine. These carbon deposits break down and mix into oil and then cause gum formation. Gummy residues, acids and resinous residues from fuel combustion can also be seen in engine oil operating under high temperature. Although the engine is equipped with an oil filter, some of the impurities will get into engine oil without being filtered, so the oil can no longer be used safely. Therefore, the engine oil and oil filter should be changed periodically (Anonymous, 2011a).

By determining the concentration of metals resulting from the wear in the engine, it is possible to determine the amount of the wear, which part of the engine is worn and whether the filter can function or not. By means of oil analysis, it is possible to take preventive measures by detecting worn products before the damage. Wear metals to be analyzed in lubricating oil are $\mathrm{Al}, \mathrm{B}, \mathrm{Cr}, \mathrm{Cu}, \mathrm{Fe}, \mathrm{Pb}, \mathrm{Mg}, \mathrm{Mo}, \mathrm{Ni}, \mathrm{Si}, \mathrm{Ag}, \mathrm{Na}, \mathrm{Sn}, \mathrm{Ti}$ and Zn. (Gökalp et al., 2007).

If successive analyzes performed at the end of the same operating times show an increase in the number of metal particles, wear is accelerated on a particular 
piece of equipment. Wear metals and source of wear are given in Table 1.

Table 1

Wear metals and source points (Anonymous 2017b)

\begin{tabular}{lc}
\hline $\begin{array}{l}\text { Wear metal and } \\
\text { Contaminants }\end{array}$ & Source \\
\hline Iron & $\begin{array}{c}\text { Cylinder, gear, bearing, body, rust, } \\
\text { piston ring, crank, liner } \\
\text { Silicon } \\
\text { Sodium } \\
\text { Potassium } \\
\text { Chrome }\end{array}$ \\
Molibden & Antifreeze \\
& Antifreeze
\end{tabular}

We examined the studies of some researchers about the change in engine lubricating oil when biodiesel was used in engine up to a certain mixing ratio. In their study, Agarwal et al (2003) used linseed oil methyl ester, diesel mixtures and diesel fuel in two similar engines respectively and they tested the engines in terms long-term durability in optimum conditions. ICP elements ( $\mathrm{Fe}, \mathrm{Cr}, \mathrm{Mg}, \mathrm{Cu}, \mathrm{Co}, \mathrm{Zn}, \mathrm{Pb}$ ) were analyzed at both engines by taking lubricating oil samples at fixed intervals. They determined that wear metals were lower in the biodiesel engine system.

Aydın and Öğüt (2017), in their study, mixed safflower oil methyl ester and diesel oil with the addition of $2.5 \%$ and $5 \%$ bioethanol at inverse proportion volumetrically and they obtained $\mathrm{E}_{2.5} \mathrm{~B}_{2.5} \mathrm{D}_{95}, \mathrm{E}_{5} \mathrm{~B}_{5} \mathrm{D}_{90}$, $\mathrm{E}_{5} \mathrm{~B}_{2.5} \mathrm{D}_{92.5}$ and $\mathrm{E}_{2.5} \mathrm{~B}_{5} \mathrm{D}_{92.5}$ mixture fuels. They tried mixture fuels and D100 fuel under partial load in a single cylinder diesel engine for 100 hours. They took samples from engine oil at certain times and examined the wear elements. As a result, they found that the most suitable fuel in terms of lubricating oil is $E_{2.5} B_{5} D_{92.5}$ compared to other fuels.

Kurre et al. (2017) stated in their study that the thinning (dilution) and oxidation of the oil were effective in engine oil contamination and in deterioration and wear of the engine parts. They stated that the degradation and useful life of the lubricating oil varies due to differences in the chemical composition of biodiesel and diesel.

In a study by Temizer and Eskici (2019), KYME10 and diesel fuel were subjected to 150 hours of work. They examined the effect of different fuels and combustion on engine lubricating oil and engine parts. As a result, compared to the study with KYME10 fuel, they found in the analyses that the engine running with M100 fuel had more metal elements in the lubricating oil.

In this study, mixture fuels were obtained by blending terebinth biodiesel, bioethanol and diesel oil in certain ratios. The obtained fuel mixtures $\mathrm{EB}_{1} \mathrm{D}_{1}$, $\mathrm{EB}_{2} \mathrm{D}_{2}, \mathrm{~EB}_{3} \mathrm{D}_{3}$ and diesel fuel were used on single cylinder diesel engine. The engine running time for each fuel was 100 hours and samples were taken from the lubricating oil every 20 hours during the trial period. Wear element analysis was performed on the lubricating oil samples and the results were evaluated.

\section{Materials and Methods}

\subsection{Material}

Terebinth biodiesel used in the research was obtained by applying transesterification method to the oil from terebint fruit. To produce biodiesel from terebint oil, "PLC Assisted Pilot Production Plant" was used, which was established with the project support numbered DPT 2004/7 within the Faculty of Agriculture at Selçuk University. Methyl alcohol was used in the transesterification reaction and sodium hydroxide was used as catalyst. A schematic view of the pilot plant is shown in Figure 1.

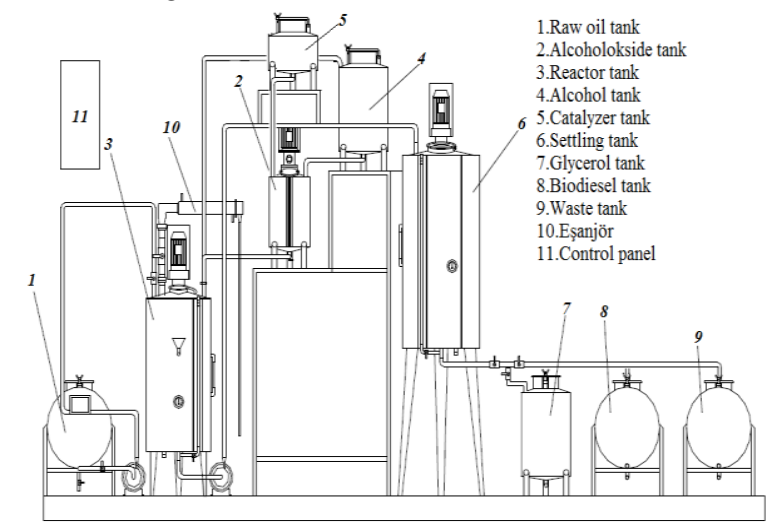

Figure 1

Schematic view of pilot production facility (Balc1, 2017)

Diesel fuel (euro diesel) and 20W50 engine oil, suitable for single cylinder diesel engine, were provided from the market. Bioethanol was obtained from Konya Sugar Industry and Trade Inc.

The engine tests were carried out in the engine testup within the Department of Agricultural Machinery and Technology Engineering, Faculty of Agriculture at Selçuk University. Schematic view of the engine test and test setup is given in Figure 2. 
The setup consists of hydraulic dynamometer, magnetic pick-up, S type loadcell, mass fuel consumption meter, dynamometer control unit and exhaust emission meter.

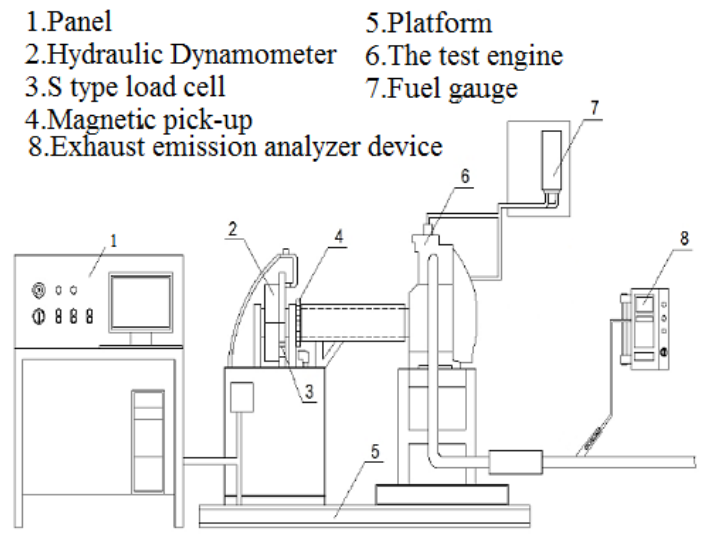

Figure 2

Schematic view of the engine test set up (Balc1, 2017)

The technical characteristics of Super Star brand single cylinder diesel test engine used in the research are given in Table 2 .

Table 2

Technical specifications of the test engine (Anonim, 2009)

\begin{tabular}{|c|c|c|}
\hline $\begin{array}{l}\text { Technical specifi- } \\
\text { cations }\end{array}$ & Unit & Value \\
\hline Working principle & - & $\begin{array}{c}4 \text { stroke direct injection } \\
\text { diesel engine }\end{array}$ \\
\hline Cylinder bore & $\mathrm{mm}$ & 108 \\
\hline Stroke & $\mathrm{mm}$ & 100 \\
\hline $\begin{array}{l}\text { Number of cylin- } \\
\text { ders }\end{array}$ & number & 1 \\
\hline Cylinder volume & 1 & 0.92 \\
\hline Compression ratio & - & $17: 1$ \\
\hline Maximum power & hp & 15 \\
\hline Maximum torque & $\mathrm{Nm}$ & 60 \\
\hline Cooling system & - & Water-cooling \\
\hline
\end{tabular}

Perkin Elmer Elan DRC-e brand ICP device, which was at Selçuk University Advanced Technology Research and Application Center laboratory, was used in Table 4

Fuel analysis results (Balc1, 2017)

\begin{tabular}{|c|c|c|c|c|c|c|c|c|c|c|}
\hline $\begin{array}{l}\text { Analysis } \\
\text { name }\end{array}$ & Unit & $\begin{array}{c}\text { Terebinth } \\
\text { oil }\end{array}$ & $\begin{array}{l}\text { Terebinth } \\
\text { Biodiesel }\end{array}$ & $\begin{array}{l}\text { TS EN } \\
14214 \\
\end{array}$ & Bioethanol & $\mathrm{D}_{100}$ & $\mathrm{~EB}_{1} \mathrm{D}_{1}$ & $\mathrm{~EB}_{2} \mathrm{D}_{2}$ & $\mathrm{~EB}_{3} \mathrm{D}_{3}$ & $\begin{array}{c}\text { TS } 3082 \\
\text { EN } 590 \\
\end{array}$ \\
\hline Kinematic & & & & & & & & & & \\
\hline $\begin{array}{l}\text { Viscosity } \\
\left(40^{\circ} \mathrm{C}\right)\end{array}$ & $\mathrm{mm}^{2} / \mathrm{s}$ & 39.18 & 4.71 & $\max .5 .0$ & 1.28 & 3.17 & 2.90 & 3.01 & 3.12 & $\max .4 .5$ \\
\hline $\begin{array}{l}\text { Density } \\
\left(15^{\circ} \mathrm{C}\right)\end{array}$ & $\mathrm{g} / \mathrm{cm}^{3}$ & 0.91 & 0.88 & $\max .0 .90$ & 0.79 & 0.84 & 0.84 & 0.84 & 0.84 & $\max .0 .84$ \\
\hline $\begin{array}{l}\text { Water } \\
\text { content }\end{array}$ & ppm & 438.78 & 303.12 & $\max .500$ & 690.56 & 24.37 & 227.59 & 286.02 & 307.45 & $\max .200$ \\
\hline $\begin{array}{l}\text { Flash } \\
\text { point }\end{array}$ & ${ }^{\circ} \mathrm{C}$ & - & 98 & $\min .01$ & - & 67 & - & - & - & $\min .55$ \\
\hline $\begin{array}{l}\text { Calorific } \\
\text { Value }\end{array}$ & $\mathrm{Mj} / \mathrm{kg}$ & - & 41.44 & - & 28.59 & 45.89 & 43.40 & 42.70 & 41.14 & - \\
\hline $\begin{array}{l}\text { Cetane } \\
\text { number }\end{array}$ & - & 57.94 & 53.47 & $\min .51$ & 13.91 & 55.84 & 51.03 & 51.19 & 51.31 & $\min .51$ \\
\hline Cloud point & ${ }^{\circ} \mathrm{C}$ & - & 7 & - & - & -4.40 & -5.45 & -4.48 & -3.90 & - \\
\hline
\end{tabular}

the analysis of the wear elements in the engine lubricating oil. The ICP-MS device allows fast, precise and accurate measurement of a large number of elements in solid and liquid samples. Thus, 76 elements in solid or liquid samples can be analyzed simultaneously and at very low concentrations (ng-pg / 1) precisely and quickly. Analysis of about 35 elements in a single sample can be measured by ICP-MS in less than three minutes ( Anonymous, 2017a).

\subsection{Method}

Four types of fuels were used in the study. They are $\mathrm{D}_{100}, \mathrm{~EB}_{1} \mathrm{D}_{1}, \mathrm{~EB}_{2} \mathrm{D}_{2}$, and EB3D3. To prepare fuel mixtures consisting of terebinth biodiesel, bioethanol and ly in a certain proportion. Mixing was carried out in the form of diesel, terebinth biodiesel and bioethanol respectively. The bioethanol content of all mixture fuels was kept constant at $2.5 \%$ and the terenbinth biodiesel and diesel ratios were variable. Table 3 gives the name of the mixture and the amounts of the mixture as $\%$ for each fuel type. As can be seen in Table $3, \mathrm{D}_{100}$ fuel is composed of $100 \%$ diesel fuel, $\mathrm{EB}_{1} \mathrm{D}_{1}$ fuel is composed of homogeneous mixture of $2.5 \%$ bioethanol, $2.5 \%$ composed of homogeneous mixture of $2.5 \%$ bioethanol, 5\% terenbinth biodiesel and $92.5 \%$ diesel fuel and $\mathrm{EB}_{3} \mathrm{D}_{3}$ fuel is composed of homogeneous mixture of $2.5 \%$ bioethanol, $7.5 \%$ terenbinth biodiesel and $90 \%$ diesel fuel.

Table 3

The names and amounts of the mixtures

\begin{tabular}{lccc}
\hline $\begin{array}{l}\text { Mixture } \\
\text { name }\end{array}$ & $\begin{array}{c}\text { Bioethanol } \\
(\%)\end{array}$ & $\begin{array}{c}\text { Terebinth } \\
\text { biodiesel }(\%)\end{array}$ & Diesel fuel (\%) \\
\hline $\mathrm{D}_{100}$ & - & - & 100 \\
$\mathrm{~EB}_{1} \mathrm{D}_{1}$ & 2.5 & 2.5 & 95 \\
$\mathrm{~EB}_{2} \mathrm{D}_{2}$ & 2.5 & 5 & 92.5 \\
$\mathrm{~EB}_{3} \mathrm{D}_{3}$ & 2.5 & 7.5 & 90 \\
\hline
\end{tabular}

Analysis results of fuel properties of terebinth oil, terebinth biodiesel, bioethanol, Diesel, $\mathrm{EB}_{1} \mathrm{D}_{1}, \mathrm{~EB}_{2} \mathrm{D}_{2}$ and $\mathrm{EB}_{3} \mathrm{D}_{3}$ fuels and standard values were given in Table 4. diesel fuel, each type of fuel was blended volumetricalterenbinth biodiesel and $95 \%$ diesel fuel, $\mathrm{EB}_{2} \mathrm{D}_{2}$ fuel is 
Table 4 (Continuation)

Fuel analysis results (Balc1, 2017)

\begin{tabular}{|c|c|c|c|c|c|c|c|c|c|c|}
\hline Pour point & ${ }^{\circ} \mathrm{C}$ & - & 1 & - & - & -25.90 & -26.88 & -25.26 & -24.02 & - \\
\hline CFPP & ${ }^{\circ} \mathrm{C}$ & - & 5 & -20 & $<-30$ & -7 & -7 & -7 & -7 & -20 \\
\hline Ash & $\%$ & 0.02 & 0.02 & $\max .0 .02$ & - & - & - & - & - & $\max .0 .01$ \\
\hline $\begin{array}{l}\text { Acid } \\
\text { number }\end{array}$ & $\underset{\mathrm{KOH} / \mathrm{g}}{\mathrm{mg}}$ & 0.56 & 0.11 & $\max .0 .50$ & - & - & - & - & - & - \\
\hline $\begin{array}{l}\text { İodine } \\
\text { number }\end{array}$ & $\begin{array}{c}\text { giodine/ } \\
100 \mathrm{~g}\end{array}$ & 70.91 & 70.91 & $\max .120$ & - & - & - & - & - & - \\
\hline $\begin{array}{l}\text { Copper } \\
\text { strip corro- } \\
\text { sion }\end{array}$ & degree & $1 \mathrm{a}$ & $1 \mathrm{a}$ & Class 1 & $1 \mathrm{a}$ & $1 \mathrm{a}$ & $1 \mathrm{a}$ & $1 \mathrm{a}$ & $1 \mathrm{a}$ & 1 \\
\hline
\end{tabular}

Each of $\mathrm{D}_{100}, \mathrm{~EB}_{1} \mathrm{D}_{1}, \mathrm{~EB}_{2} \mathrm{D}_{2}$ and $\mathrm{EB}_{3} \mathrm{D}_{3}$ fuels were operated under partial load for 100 hours and samples were taken from the lubricating oil during engine tests. 5 samples were collected at the end of 100 hours of operation with 20 hours intervals for each fuel, and totally 20 oil samples were taken from all fuels. Analyzes of $\mathrm{Fe}, \mathrm{Cu}, \mathrm{Al}, \mathrm{Pb}, \mathrm{Cr}$ elements in unused engine oil and 20 oil samples were performed by ICP (Inductively Coupled Plasma) device at Selçuk University, Advanced Technology Research and Application Center Laboratory.

\section{Results and Discussion}

\subsection{Aluminium (Al)}

Aluminum element originates from pistons, piston head and rings and bearings. It can be detected at high rates especially in the samples taken as a result of the first operating hours after the machine production and revision. When this metallic formation is high in the analysis results, it is thought that there is oil filter contamination and there are problems in air intake circuit, valve caps and crankcase. In addition, excessive oil consumption, loss of performance, abnormal machine noise may occur in later stages of this formation (Lukas and Anderson, 1998; Müjdeci, 2009).

The amount of aluminum element in the engine lubricating oil depending on the operating time of $\mathrm{D}_{100}$, $\mathrm{EB}_{1} \mathrm{D}_{1}, \mathrm{~EB}_{2} \mathrm{D}_{2}, \mathrm{~EB}_{3} \mathrm{D}_{3}$ fuels is given in Table 5 and the graphical expression of these values is given in Figure 3.

Table 5

The amount of aluminum element

\begin{tabular}{|c|c|c|c|c|c|}
\hline 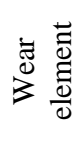 & 哥 & $\begin{array}{l}\mathrm{D}_{100} \\
(\mathrm{ppb})\end{array}$ & $\begin{array}{c}\mathrm{EB}_{1} \mathrm{D}_{1} \\
(\mathrm{ppb})\end{array}$ & $\begin{array}{c}\mathrm{EB}_{2} \mathrm{D}_{2} \\
(\mathrm{ppb})\end{array}$ & $\begin{array}{c}\mathrm{EB}_{3} \mathrm{D}_{3} \\
(\mathrm{ppb})\end{array}$ \\
\hline \multirow{6}{*}{$\underset{\mathrm{E}}{\stackrel{\Xi}{\Xi}}$} & 20. h & 3147.81 & 2792.66 & 2353.44 & 961.58 \\
\hline & 40. h & 3060.93 & 2948.72 & 2588.64 & 913.36 \\
\hline & $60 . \mathrm{h}$ & 3459.32 & 3285.45 & 2765.13 & 1005.54 \\
\hline & 80. h & 3857.70 & 3572.91 & 2982.25 & 1158.16 \\
\hline & 100. h & 4174.86 & 3827.65 & 3227.20 & 1306.78 \\
\hline & $0 . \mathrm{h} * *$ & \multicolumn{4}{|c|}{1529.77} \\
\hline
\end{tabular}

Limit values* $\quad 15-40 \mathrm{ppm}(15000-40000 \mathrm{ppb})$

*Özçelik (2011)

***ean oil

When the amount of $\mathrm{Al}$ element in engine lubricating oil is examined in Figure 3, it is observed that there are certain increases in $\mathrm{D}_{100}, \mathrm{~EB}_{1} \mathrm{D}_{1}, \mathrm{~EB}_{2} \mathrm{D}_{2}, \mathrm{~EB}_{3} \mathrm{D}_{3}$ fuels from the 20 th hour to the end of the 100 th hour.

At the same time, in addition to bioethanol $(2.5 \%)$ which was a constant value in the mixture fuels, it was determined that the amount of $\mathrm{Al}$ element decreased compared to $\mathrm{D}_{100}$ fuel according to the increasing amount of biodiesel $(2.5 \%, 5 \%$ and $7.5 \%)$. As can be seen in Table 5, the highest increase compared to clean oil (0.h) was realized as $172.90 \%$ at 100 th hours in D100 fuel. The amount of aluminum elements remained within the limit values. Compared to $\mathrm{D}_{100}$ fuel, the increase rate of $\mathrm{Al}$ element in $\mathrm{EB}_{1} \mathrm{D}_{1}, \mathrm{~EB}_{2} \mathrm{D}_{2}$, $\mathrm{EB}_{3} \mathrm{D}_{3}$ fuels from the 20th hour to the 100th hour was $3.58 \%, 13.78 \%, 10.02 \%$ respectively.

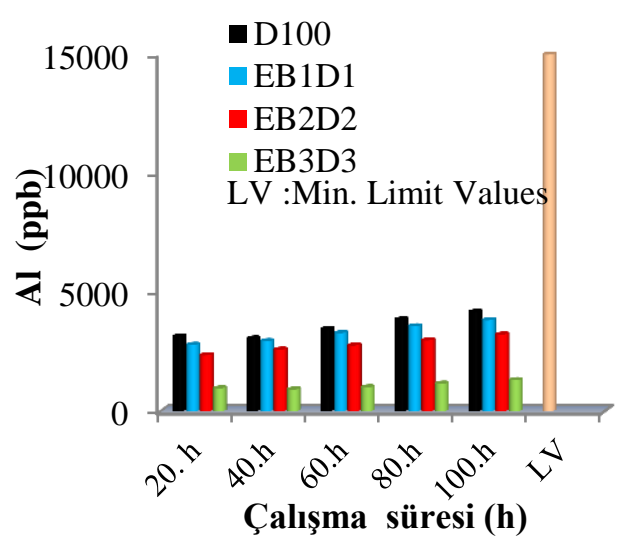

Figure 3

Aluminum element

\section{2. $\operatorname{Iron}(\mathrm{Fe})$}

Iron element is the most important metallic particle that determines the changing period of lubricating oil. The presence of an excess of metallic formation causes problems such as excessive oil consumption, abnormal

machine noise, performance problems, abnormal oil pressure and operating temperatures, defective piston rings and rust formation in the system (Lukas ve Anderson, 1998; Müjdeci, 2009).

Table 6 shows the amount of iron element in the engine lubricating oil depending on the operating time of $\mathrm{D}_{100}, \mathrm{~EB}_{1} \mathrm{D}_{1}, \mathrm{~EB}_{2} \mathrm{D}_{2}, \mathrm{~EB}_{3} \mathrm{D}_{3}$ fuels. The graphical expression of these data is also shown in Figure 4.

According to the results of the study, as the operating time of $\mathrm{D}_{100}, \mathrm{~EB}_{1} \mathrm{D}_{1}, \mathrm{~EB}_{2} \mathrm{D}_{2}, \mathrm{~EB}_{3} \mathrm{D}_{3}$ fuels increased, Fe element amount increased as well. In addition, as a result of the evaluations made from the 20th hour to the 100th hour of the operation time, Fe element amounts 
of $\mathrm{EB}_{1} \mathrm{D}_{1}, \mathrm{~EB}_{2} \mathrm{D}_{2}, \mathrm{~EB}_{3} \mathrm{D}_{3}$ fuels increased at the rate of $65.56 \%, 29.04 \%, 23.55 \%$ respectively compared to $\mathrm{D}_{100}$ fuel. In addition, the highest amount of iron elements was found in $E-B_{1}-D_{1}$ fuel. The amount of $\mathrm{Fe}$ element in all fuels did not exceed the limit values. Compared to clean oil, the highest increase rate was $254.05 \%$ in $\mathrm{EB}_{1} \mathrm{D}_{1}$ fuel at 100 th hour.

Table 6

The amount of iron element

\begin{tabular}{|c|c|c|c|c|c|}
\hline 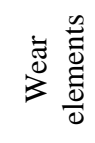 & 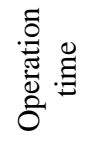 & $\begin{array}{l}\mathrm{D}_{100} \\
(\mathrm{ppb})\end{array}$ & $\begin{array}{c}\mathrm{EB}_{1} \mathrm{D}_{1} \\
(\mathrm{ppb})\end{array}$ & $\begin{array}{c}\mathrm{EB}_{2} \mathrm{D}_{2} \\
(\mathrm{ppb})\end{array}$ & $\begin{array}{c}\mathrm{EB}_{3} \mathrm{D}_{3} \\
(\mathrm{ppb})\end{array}$ \\
\hline \multirow{6}{*}{ 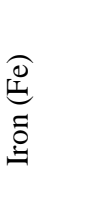 } & $20 . \mathrm{h}$ & 38088.06 & 41904.58 & 23177.38 & 20808.04 \\
\hline & $40 . \mathrm{h}$ & 37041.94 & 44749.97 & 22429.68 & 21719.81 \\
\hline & $60 . \mathrm{h}$ & 41741.64 & 43757.09 & 23760.63 & 23999.65 \\
\hline & 80. h & 50546.47 & 59982.01 & 27961.58 & 23140.08 \\
\hline & 100. h & 51983.76 & 67215.83 & 34089.58 & 30187.35 \\
\hline & $0 . \mathrm{h}^{* *}$ & \multicolumn{4}{|c|}{18984.4} \\
\hline \multicolumn{2}{|c|}{ Limit values* } & \multicolumn{4}{|c|}{$40-200 \mathrm{ppm}(40000-200000 \mathrm{ppb})$} \\
\hline
\end{tabular}

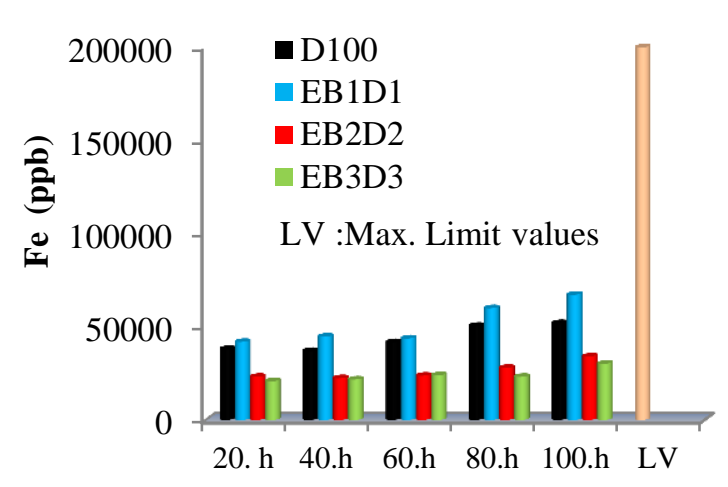

Çalışma süresi (h)

Figure 4

Iron Element

\section{3. $\operatorname{Lead}(\mathrm{Pb})$}

The lead element may be caused by wear of plain bearings or tin-lead mixture soldering joints and some sealing elements. However, the lead element can result from fuel as well as from gear system clutches and brake friction plates (Lukas and Anderson, 1998; Müjdeci, 2009).

The amount of lead element in the engine lubricating oil, depending on the operating time of $\mathrm{D}_{100}$, $\mathrm{EB}_{1} \mathrm{D}_{1}, \mathrm{~EB}_{2} \mathrm{D}_{2}, \mathrm{~EB}_{3} \mathrm{D}_{3}$ fuels, is given in Table 7 and the graph of these values is given in Figure 5.

When Table 7 is examined, it is seen that $\mathrm{Pb}$ values increased as operating time of $\mathrm{D}_{100}, \mathrm{~EB}_{1} \mathrm{D}_{1}, \mathrm{~EB}_{2} \mathrm{D}_{2}$, $\mathrm{EB}_{3} \mathrm{D}_{3}$ fuels increased and all data remained within the limit values. Compared to $\mathrm{D}_{100}$ fuel, the amount of $\mathrm{Pb}$ element in the engine lubricating oil from the 20th to the 100th hours increased by $47.61 \%, 97.69 \%, 38.57 \%$ respectively in $\mathrm{EB}_{1} \mathrm{D}_{1}, \mathrm{~EB}_{2} \mathrm{D}_{2}, \mathrm{~EB}_{3} \mathrm{D}_{3}$ fuels. The highest increase compared to clean oil (0.h) was $144.46 \%$ in $\mathrm{D}_{100}$ fuel at 100th hour.

Table 7

The amount of iron element

\begin{tabular}{|c|c|c|c|c|c|}
\hline 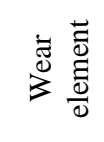 & 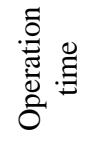 & $\begin{array}{c}D_{100} \\
(\mathrm{ppb})\end{array}$ & $\begin{array}{c}\mathrm{EB}_{1} \mathrm{D}_{1} \\
(\mathrm{ppb})\end{array}$ & $\begin{array}{c}\mathrm{EB}_{2} \mathrm{D}_{2} \\
(\mathrm{ppb})\end{array}$ & $\begin{array}{c}\mathrm{EB}_{3} \mathrm{D}_{3} \\
(\mathrm{ppb})\end{array}$ \\
\hline & $20 . \mathrm{h}$ & 1284.88 & 948.79 & 940.91 & 612.66 \\
\hline & $40 . \mathrm{h}$ & 1195.44 & 936.75 & 987.05 & 675.98 \\
\hline zo & $60 . \mathrm{h}$ & 1402.66 & 745.03 & 879.54 & 689.09 \\
\hline & $80 . \mathrm{h}$ & 1489.06 & 832.16 & 979.62 & 616.37 \\
\hline & $100 . \mathrm{h}$ & 1584.05 & 1274.90 & 1374.03 & 810.36 \\
\hline & $0 . h^{* *}$ & \multicolumn{4}{|c|}{647.96} \\
\hline Limit va & alues* & \multicolumn{4}{|c|}{$5-40 \mathrm{ppm}(5000-40000 \mathrm{ppb})$} \\
\hline
\end{tabular}

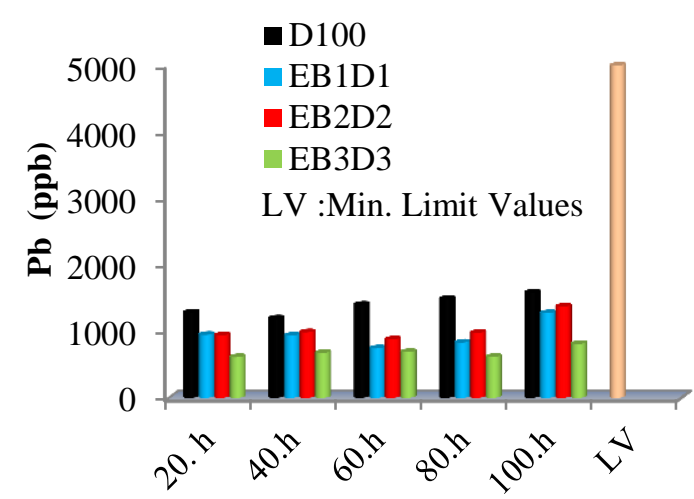

Çalışma süresi (h)

Figure 5

Lead Element

\subsection{Copper $(\mathrm{Cu})$}

Copper element can be realized in gear and valve plates, gear types, turbocharger bearings, cam bearings and piston pin bearings, many gear systems with high copper content and in brake plates containing sintered bronze. In addition, corrosion formation in oil cooling system should be considered in case of high copper level (Avc1, 2009).

The copper values of lubricating oil depending on operating time of $\mathrm{D}_{100}, \mathrm{~EB}_{1} \mathrm{D}_{1}, \mathrm{~EB}_{2} \mathrm{D}_{2}, \mathrm{~EB}_{3} \mathrm{D}_{3}$ fuels are given in Table 8 and graph of values is given in Figure 6. 
Table 8

The amount of copper element

\begin{tabular}{|c|c|c|c|c|c|}
\hline 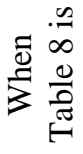 & 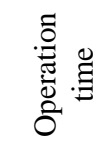 & $\begin{array}{l}\mathrm{D}_{100} \\
(\mathrm{ppb})\end{array}$ & $\begin{array}{l}\mathrm{EB}_{1} \mathrm{D}_{1} \\
(\mathrm{ppb})\end{array}$ & $\begin{array}{l}\mathrm{EB}_{2} \mathrm{D}_{2} \\
(\mathrm{ppb})\end{array}$ & $\begin{array}{l}\mathrm{EB}_{3} \mathrm{D}_{3} \\
(\mathrm{ppb})\end{array}$ \\
\hline \multirow{6}{*}{$\begin{array}{l}\overline{\bar{d}} \\
\hat{2} \\
\overline{0}\end{array}$} & 20. $\mathrm{h}$ & 5497.82 & 1436.64 & 1536.28 & 1458.80 \\
\hline & 40. $\mathrm{h}$ & 6193.84 & 1339.02 & 1576.59 & 1811.56 \\
\hline & 60. h & 5050.20 & 1490.36 & 1743.97 & 1976.00 \\
\hline & 80. $\mathrm{h}$ & 6579.55 & 1393.94 & 1845.01 & 1708.88 \\
\hline & 100. h & 6797.30 & 1878.96 & 2099.43 & 1738.60 \\
\hline & $0 . \mathrm{h} * *$ & \multicolumn{4}{|c|}{2909.48} \\
\hline \multicolumn{2}{|c|}{ Limit values $*$} & \multicolumn{4}{|c|}{$5-40 \mathrm{ppm}(5000-40000 \mathrm{ppb})$} \\
\hline
\end{tabular}

Compared to $\mathrm{D}_{100}$ fuel, $\mathrm{Cu}$ element amount increased by $30.25 \%, 55.08 \%$ in $\mathrm{EB}_{1} \mathrm{D}_{1}, \mathrm{~EB}_{2} \mathrm{D}_{2}$ fuels; and decreased by $18.85 \%$ in $\mathrm{EB}_{3} \mathrm{D}_{3}$ fuel compared to diesel. According to the evaluation made according to clean oil (0.h), the highest increase was seen in $D_{100}$ fuel at 100th hour with $133.62 \%$ value.

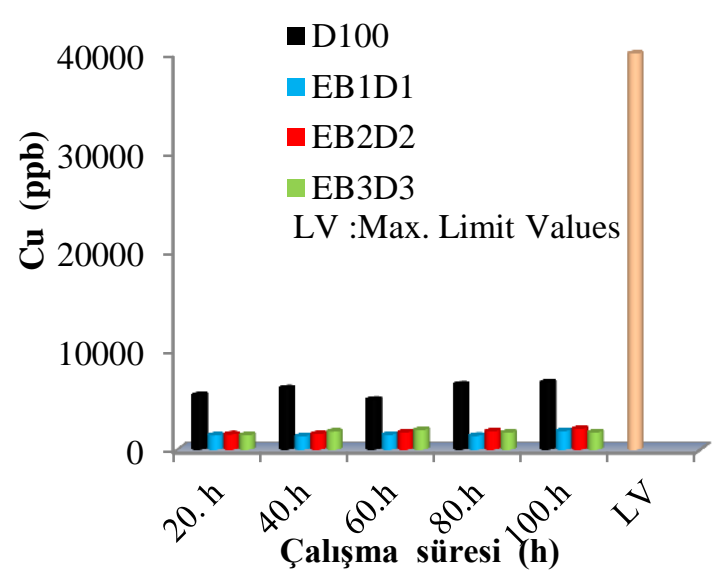

Figure 6

Copper element

\subsection{Chrome $(\mathrm{Cr})$}

Chrome element is generally used as coating material of machine elements. Piston rings coated with chrome, chrome and chrome alloy machine parts form the source of this metal. It can also be caused by gasket, cylinder and some bearing elements. Increased pollution of air in the cylinder and defective segments increase the proportion of this metal. Cr increase is an indication of excessive oil consumption, leakage in the machine or deterioration of oil quality (Lukas and Anderson, 1998; Avc1, 2009).

Chrome element values of engine lubricating oil and the gragh of these values depending on the operation time of $\mathrm{D}_{100}, \mathrm{~EB}_{1} \mathrm{D}_{1}, \mathrm{~EB}_{2} \mathrm{D}_{2}, \mathrm{~EB}_{3} \mathrm{D}_{3}$ fuels are given in Table 9 and Figure 7 respectively.
Table 9

The amount of chrome element

\begin{tabular}{|c|c|c|c|c|c|}
\hline 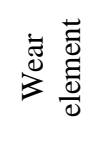 & 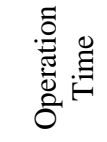 & $\begin{array}{l}\mathrm{D}_{100} \\
(\mathrm{ppb})\end{array}$ & $\begin{array}{c}\mathrm{EB}_{1} \mathrm{D}_{1} \\
(\mathrm{ppb})\end{array}$ & $\begin{array}{c}\mathrm{EB}_{2} \mathrm{D}_{2} \\
(\mathrm{ppb})\end{array}$ & $\begin{array}{c}\mathrm{EB}_{3} \mathrm{D}_{3} \\
(\mathrm{ppb})\end{array}$ \\
\hline \multirow{6}{*}{$\underset{\Xi}{\stackrel{\Xi}{U}}$} & 20. $\mathrm{h}$ & 5009.61 & 5370.07 & 5452.19 & 4572.14 \\
\hline & 40. h & 5926.42 & 5614.76 & 5825.16 & 4919.46 \\
\hline & 60. h & 6075.83 & 5574.89 & 5927.10 & 4892.23 \\
\hline & 80. h & 6057.48 & 5345.96 & 6145.07 & 5320.77 \\
\hline & 100. h & 5777.12 & 5755.07 & 6234.69 & 5758.55 \\
\hline & $0 . \mathrm{h}^{* *}$ & \multicolumn{4}{|c|}{5747.15} \\
\hline \multicolumn{2}{|c|}{ Limit values* } & \multicolumn{4}{|c|}{$10-30 \mathrm{ppm}(10000-30000 \mathrm{ppb})$} \\
\hline
\end{tabular}

When Table 9 is examined, as engine running time increased in $\mathrm{D}_{100}, \mathrm{~EB}_{1} \mathrm{D}_{1}, \mathrm{~EB}_{2} \mathrm{D}_{2}, \mathrm{~EB}_{3} \mathrm{D}_{3}$ fuels, the amount of chrome increased as well. It is seen that the amount of chrome element in all fuel types is within the limit values.

Compared to $\mathrm{D}_{100}$ fuel, the amount of $\mathrm{Cr}$ element in $E B_{1} D_{1}$ ve $E B_{2} D_{2}$ fuels from 20th to 100th hours decreased by $53.20 \%, 7.68 \%$ respectively; but in $\mathrm{EB}_{3} \mathrm{D}_{3}$ fuel it increased by $69.36 \%$ compared to diesel fuel. According to the evaluation of clean oil, the highest increase was in $\mathrm{EB}_{2} \mathrm{D}_{2}$ fuel with $8.48 \%$ at 100th hour.

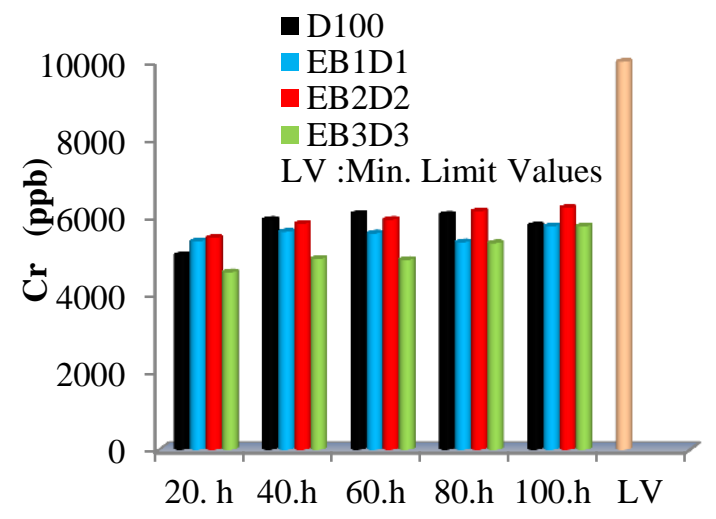

Çalışma süresi (h)

Figure 7

Chrome element

\section{Conclusion}

When the wear element analysis data of the engine lubricating oil were evaluated in the samples taken from all fuel types, it was found that the wear element amount increased as the engine operating time increased. Compared to $\mathrm{D}_{100}$ fuel, there was a decrease in wear elements in $\mathrm{EB}_{1} \mathrm{D}_{1}, \mathrm{~EB}_{2} \mathrm{D}_{2}, \mathrm{~EB}_{3} \mathrm{D}_{3}$ fuels. The effect of lubricating of biodiesel confirms these results. Only in $\mathrm{EB}_{1} \mathrm{D}_{1}$ fuel, iron content is higher than $\mathrm{D}_{100}$ fuel. The amount of wear elements in all mixtures remained within the limit values.

When the increase rate of wear element analysis from 20th hour to 100th hour is evaluated according to $D_{100}$, the lowest ratios were obtained in $E_{3} D_{3}$ fuel 
among fuel mixtures in element analysis results except $\mathrm{Cr}$ element. The amount of $\mathrm{Cr}$ element in $\mathrm{EB}_{3} \mathrm{D}_{3}$ fuel is within the limit values.

According to the results of the study, the best results were obtained from $\mathrm{EB}_{3} \mathrm{D}_{3}$ fuel when the engine lubricating oil data were evaluated compared to $D_{100}$ fuel.

Symbol \& abbreviations

Ag : Silver

Al : Aluminium

B : Boron

CFPP : Cold filter plugging point

$\mathrm{Cr} \quad$ : Choreme

$\mathrm{Cu} \quad$ : Copper

Co : Cobalt

$\mathrm{D}_{100} \quad$ : Diesel

DPT : State planning organisation

DRC : Dynamic Reaction Cell

$\mathrm{EB}_{1} \mathrm{D}_{1} \quad: \quad 2.5 \%$ bioethanol $+2.5 \%$ biodiesel + $95 \%$ diesel

$\mathrm{EB}_{2} \mathrm{D}_{2} \quad: \quad 2.5 \%$ bioethanol $+5 \%$ biodiesel + $92.5 \%$ diesel

$\mathrm{EB}_{3} \mathrm{D}_{3} \quad: \quad 2.5 \%$ bioethanol $+7.5 \%$ biodiesel + $90 \%$ diesel

$\mathrm{Fe} \quad$ : Iron

ICP : Inductively Coupled Plasma

KOH : Potassium hydroxide

KYME10 : Canalo oil methly ester $\% 10+\% 90$ diesel

$\mathrm{Mg} \quad$ : Magnesium

Mo : Molibden

$\mathrm{Na} \quad$ : Sodium

Ni : Nickel

$\mathrm{Pb} \quad$ : Lead

PLC : Programmable logic controller

ppb : part per billion

ppm : part per million

$\mathrm{Si} \quad$ : Silicon

Sn : Tin

Ti : Titanium

Zn : Zinc

\section{Acknowledgements}

This study is a part of Ayşe betül BALCI's doctoral dissertation and the research was supported by Selçuk University Scientific Research Projects Coordination Unit with project numbered 15201034.

\section{References}

Agarwal AK, Bijwe J, Das LM (2003). Wear assessment in a biodiesel fueled compression ignition en- gine, Journal of Engineering for Gas Turbines and Power, 125, 820-826.

Anonymous (2009). Super star diesel engine operation and maintenance manual, İstanbul.

Anonymous (2011a). Motor vehicle technology, Automotive periodic maintenance, T.C. Ministry of Education, Ankara.

Anonymous (2011b). Rail systems teknology, diesel engine lubricating systems, T.C. Ministry of Education, Ankara.

Anonymous (2017a). ICP - MS

http://www.selcuk.edu.tr/ileri teknoloji_aras uyg mrkz mud/birim/web/sayfa/ayrinti/5875/tr (visit date: 15.02.2017).

Anonymous (2017b). Lubrication engineers the oil analysis program, www.leturkey.com (visit date: 10.02.2017).

Aydın F, Öğüt H (2017). The effect of E-B diesel fuel blends on engine lubricating oil in a single cylinder diesel engine, International Journal of Automotive Engineering and Technologies, vol.6, Issue 3, pp 129-139

Avc1 A (2009). Oil drain 1nterval analysis of 6 diesel light duty commercial vehicles servicing for a parcel service firm in Turkey, Master Thesis, The Graduate School of Natural and Applied Science of Yıldız Technical University, İstanbul

Balc1 AB (2017). Investigation for effects of bioethanol and terebinth biodiesel blends with diesel to performance, exhaust emissions and lubricating oil in diesel engine, Ph.D thesis, The Graduate School of Natural Science of Selçuk University, Konya

Gökalp B, Saraç Hİ, Çelik C (2007). Destruction analysis depend on the wearing with oil analysis program, Prooceedings of 8 th International Fracture Conference, 7 - 9 November, İstanbul, pp 651-664.

Kurre SK, Garg R, Pandey S (2017). A review of biofuel generated contamination, engine oil degradation and engine wear. Biofuels, 8(2), 273-280.

Lukas M, Anderson DP (1998). Laboratory used oil analysis methods, Lubrication Engineering, 54 (11), 19-23.

Müjdeci S (2009). Experimental analysis of the effect of commercial oil additives on friction, wear and engine performance in an internal combustion engine, Ph.d. Thesis, The Graduate School of Natural and Applied Science of Yildız Technical University, İstanbul

Temizer İ, Eskici B (2019). Analysis of engine oil and piston rings as a result of using canola oil methyl ester / diesel fuel in an internal combustion diesel engine, Afyon Kocatepe University Journal of Science and Engineering, 19 (2019), 025901 (449-460)

Özçelik AE (2011). Determination of the effect of safflower biodiesel and its blends with diesel fuel on lubricating oil in a single cylinder diesel engine, Ph.d. Thesis, The Graduate School of Natural Science of Selçuk University, Konya 